\title{
THE VILLA, IDENTITY COMPONENT IN THE TOURISM INFRASTRUCTURE OF BORSEC SPA RESORT
}

\author{
G. B. TOFAN"1, A. NIŢĂ²
}

\begin{abstract}
The Villa, Identity Component in the Tourism Infrastructure of Borsec Spa Resort. Our study intends to emphasize several trends concerning the dynamic of a classic accommodation component (villa), currently experiencing a revival and rehabilitation in Borsec. In regards to this last aspect, one must point out that most investors are from the Republic of Moldova, Hungary and Israel. In Borsec, this form of accommodation was dominant at the beginning of the 1990s, but due to severe wear and tear and gradual closures, the accommodation structure began to change in 2004 , villas being slowly replaced by tourist pensions. This situation was further exacerbated by difficult road and railway connections, traffic requiring transhipment. The closest railway station is in the town of Topliţa, $25 \mathrm{~km}$ away, while the Târgu Mureş “Transylvania” International Airport is located roughly $140 \mathrm{~km}$ away. In the last couple of years, a lot of attention was focused on county road 128 (Borsec-Jolotca), since it is an investment crucial for the tourists visiting Borsec, by shortening the distance by $30 \mathrm{~km}$ to the county capital, Miercurea-Ciuc. Another noteworthy aspect is that in February 2017, the Government Decree no. 9 restated the town of Borsec as a national tourism resort.
\end{abstract}

Keywords: spa resort, mineral waters, villas, wear and tear, rehabilitation.

\section{INTRODUCTION}

The town of Borsec is located in the Central Group of the Eastern Carpathians, overlapping the homonymous basin, developed along Vinului Stream, a right-side tributary of Bistricioara River. It is a part of Corbu-Tulgheş depression alignment, alongside Drăgoiasa, Bilbor, and Secu basins, in the long line of mountain basins

\footnotetext{
1 „Vasile Goldiş” Western University of Arad, Faculty of Economic Sciences, Engineering and Informatics, Departament of Engineering and Informatics, Baia Mare Branch, 5 Culturii Street, Romania, e-mail: bogdan.tofan@uvvg.ro.

2 „Babeș-Bolyai” University, Faculty of Geography, Gheorgheni Branch, Csiki Garden, Romania, e-mail: nitaadrian@hotmail.com.
} 
that divide the volcanic and the crystalline mountain ranges. Borsec is a former Pliocene volcanic dam lake bed, hosting coal deposits, with an area of $20.4 \mathrm{~km}^{2}$ (Tofan, 2013). Initially, it was a Subcarpathian depression drained by a westward hydrographic network, towards the lake located in the Transylvanian Basin.

The Neogene volcanic eruptions isolated and fragmented the rivers, which meant that the sectors located west of the volcanic barrier, with lower flows, kept their old lines, while the eastern ones, originating in the central crystalline, created the Dacian-Levantine Lake of Borsec. Borsec Basin is located at the triple junction area between Bistricioara Mountains (to the North-East), Căliman Mountains (to the North-West) and Giurgeu Mountains (to the South). Similarly to the other basins that make up Drăgoiasa-Tulgheş depression alignment, it has a dual compartment structure, comprising two small interconnected basins (Borsecul de Sus, smaller, in the northern part, and Borsecul de Jos or Tinoave, larger, to the South), divided by a large erosional gap formed along a tectonic line between Dealul Rotund and the slopes of Arcozei.

The area has an important hydrographic potential, mainly due to the mineral waters of the Căliman-Harghita mofetta, which led to the existence, ever since the $16^{\text {th }}$ century, of the so-called "Mineral water civilization". Thus, the mineral waters of the area helped create a certain type of territorial development and a certain type of tourism, the spa tourism, seen as a "journey”, taken for treatment, recovery or illness prevention, in the case of people with functional deficiencies, for rest and relaxation, through therapeutical treatments.

\section{WORK METHODOLOGY}

Villas (rest and treatment houses) are traditional tourism accommodation structures, located in spa resorts, used for treatment, rest and recreation (N. Ciangă, 1997). The villa is the oldest accommodation unit, permanent in nature, larger than hostels, with up to several tens of beds, low comfort, containing rooms with multiple (three or four) beds and lacking room bathrooms, used exclusively for sleeping.

For a clear view on this category, we resorted to field research and used two sets of statistical data: one from The National Institute of Statistics and one from The National Tourism Authority, part of the Ministry of Tourism. This enabled us to conduct a broader analysis of the spatial dynamic of Borsec villas, after the transition period.

Furthermore, this endeavour is based on a series of papers and studies (Orban, 1868; Răucescu \& Cozan, 1977; Călimănescu \& Zaharia, 1981; Ciangă, 1997; Ciangă \& Dezsi, 2007; Farkas, 2004, 2007; Grama \& Negru, 2012; Tofan, 2012, 2013, 2014; Tofan, \& Niţă, 2014, 2015), as well as on several sustainable tourism development strategies and planning codes. 


\section{SHORT HISTORY OF BORSEC VILLAS}

The tourism development of the studied area began at the end of the $19^{\text {th }}$ century, when the first rest (treatment) houses were built close to the mineral water springs. The tourism capacity was rather limited, and the entire organisation relied on catering to a limited number of clients at high prices (Ciangă \& Dezsi, 2007).

The villas were built following a "Swiss" architectural style (Fachwerk type), on wooden structures, and having steepled roofs. Their terraces and balconies were large, elaborately ornated and spacious (Farkas, 2007). However, the vast majority were not created to host visitors during winter, which created a certain seasonality in the resort.

Between 1852 and 1853, the resort physician, after reviewing the improper conditions found in the area, tried to embolden the improvement of services, in order to attract a greater number of tourists, stating that: „In Borsec, the villas are as expensive as they are improper. Most are damp, unhealthy, where the wind blows unhindered not only through walls, but through floors as well. During rainy days, water slips through the degraded roofs. Rooms are low, windows are small, disrupting the wellness and health of tourists even in good weather, but when summers are wet and cold, pacients have to spend their time inside. The waters of Borsec deserve buildings with the most beautiful furniture which would bring profits as nowhere else in Transylvania" (Orban, 1868).

In 1890, Borsec had 34 villas and three hotels, with roughly 350 rooms (Farkas, 2007). The most important revival took place in the interwar period, when most villas were built, continuing the same well-proportioned architectural style, with delicate woodwork, especially in their pediments, which gave each villa its uniqueness. Some villas had several floors, the ground floor hosting multiple shops. Many buildings in Borsecul de Sus were privately owned, many villas carrying their owners name (Szalkay, Barbu, Smilovits, Ștefănescu, Ágnes, Emilia, Sofia, Stoica, Mélik etc). Besides single owners, many public institutions had villas in the area, such as Ditrău and Lăzarea forestry associations, Caritas, Ciuc Private Goods, etc. When the nationalization law was enforced, villas became property of several ministries (Ministry of Health, Ministry of Transport, Defence Ministry), and were administered by L. S. E Borsec (Local Spa Enterprise), which later became S. R. E Borsec (The Spa-Resort Enterprise). Following this change, villas were modernised and rehabilitated, their degree of comfort increased, in order for them to function in winter as well. In 1956, with the help of massive investment, as well as due the diversification of the functional profile, Borsec became a town, with a population of 2,318 (Tofan \& Niţă, 2015). 
In 1976, Borsec had a total of 65 villas, divided into comfort categories, with a total capacity of 2,646 beds, 1,744 permanent and 902 seasonal. The comfort level of permanent villas was as follows: level A-92 beds; level I-586 beds; level II-898 beds; level III-168 beds, while the situation of seasonal villas was: level I- 2 beds; level II- 451 beds; level III- 449 beds. Besides villas, there were two lodges ( 86 beds), 78 cabins ( 156 beds) and a series of local households ( 150 beds) (data collected by Răucescu and Cozan, Borsec Tourism Office, file no. 562/1976).

After 1989, SRE Borsec was transfered to the State Property Fund and became a joint-stock company, named "Commercial Joint Stock Tourism Company" (S. J. S. T. C).

One investor bought the stock majority, sold some of the villas, while the ones remaining in S. J. S. T. C property were acquired by other investors. Some unsold villas were bought by the Romanian Commercial Bank, which put them out for auction. Due to severe lack of funds for rehabilitation and tourism strategies, the numbers of villas from both categories decreased. Spa life based on state grants was no longer feasible in the market economy and due to its decaying infrastructure, Borsec went into decline.

After 2001, the tourism activity in the resort was continued by small investors and private entrepreneurs, which solely provided accommodation and food services. Borsec was therefore "downgraded" from a national to a local resort. The tourism peak of Borsec took place in the 1970s and 1980s, but due to closures and the decay of its infrastructure, the accommodation structure of the area began to change, villas being slowly replaced by hostels.

\section{THE ACCOMMODATION CAPACITY OF VILLAS}

According to the data provided by the National Institute of Statistics, the TEMPO- Online database, in 1990, Borsec had a complex and rather considerable accommodation infrastructure, comprising 2,833 beds. Villas had 2,559 beds $(90.3 \%)$ while camping sites only 274 (9.7\%). One year later (1991), the accommodation capacity decreased by 504 beds (10 units), in hotels by 103 (4\%), in villas by 2,068 (88\%) and in camping areas by 190 (8\%). From 1990 to 2016 the number of functional villas dropped from 71 to only 2 , and the number of beds from 2,559 to just 96 , which means a decrease of $97.2 \%$ and $96.2 \%$ respectively in 26 years. 


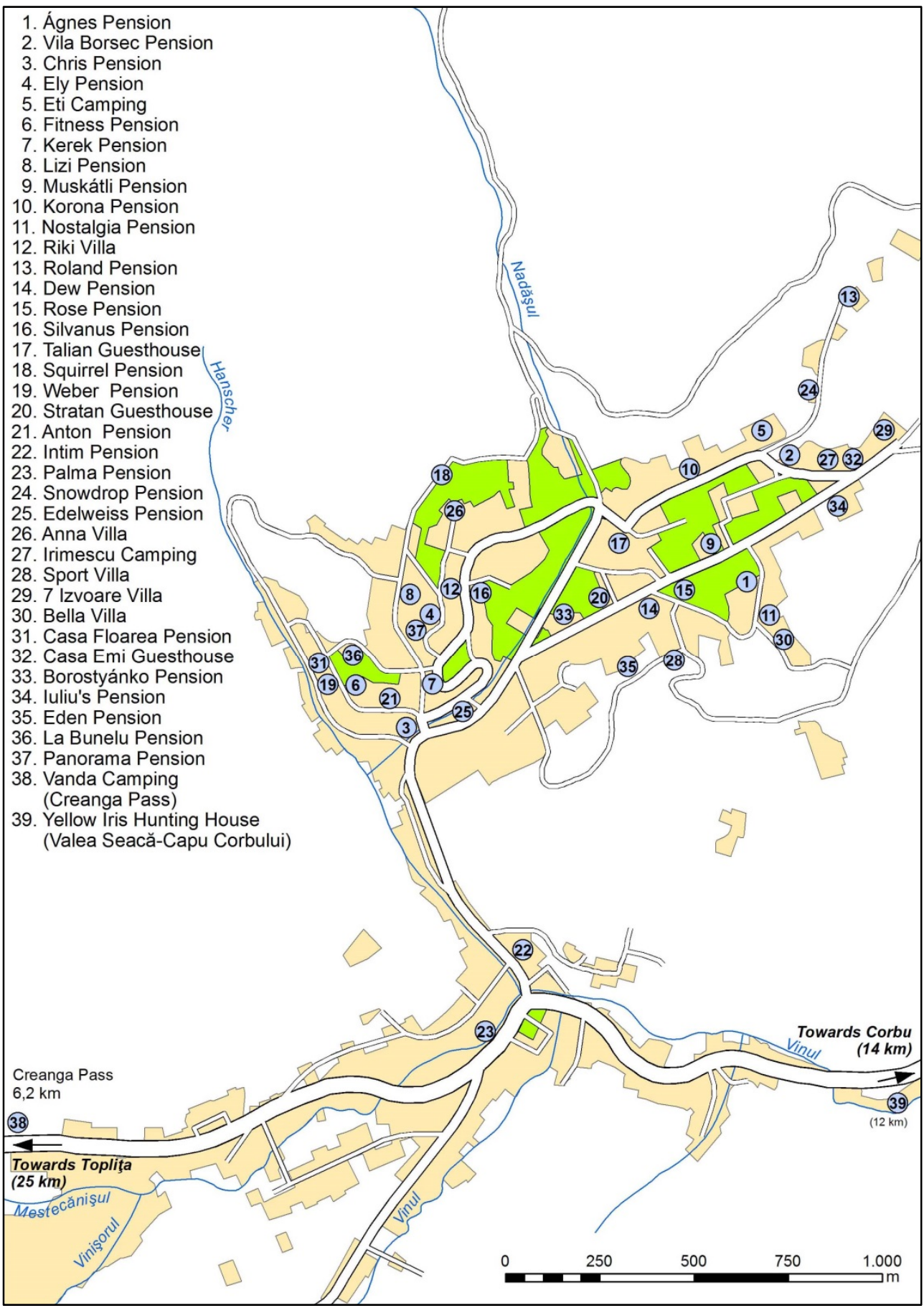


The main cause was the lack of investment in this type of establishments and the degradation of existing villas, most of them losing their classification and being put out of use. The 71 villas belonged to several owners, very few from Borsec, most of them being from Kuwait, Ireland, India, the US, Canada, Israel, Hungary, Republic of Moldova or Croatia, who never performed maintenance on them. There have been owners who received their villas back through retrocession, but sold them to various individuals and organisations, leading to the current dire situation. Fraudulent privatizations, the total withdrawal of authorities from the management of the resort, as well as shady local and foreign Hungarian interests were among the causes for the disappearance of villas in the area. Strangely, even though a part of the villas are degraded, due to lack of upkeep (especially those built between 1960 and 1980), and tourists are still rare in Borsec, the price of some of them exceeds 70,000 euro, currently over 10 villas having been rehabilitated.

In 2011, through a pilot project coordinated by the Ministry of Regional Development and Tourism, alongside the United Nations, a law was published in the Official Monitor, stating that all owners of villas in Borsec, Băile Herculane and Sulina must retrofit their units and return them to the tourism circuit. In case of noncompliance, they will be expropriated and the state will complete the above mentioned task.

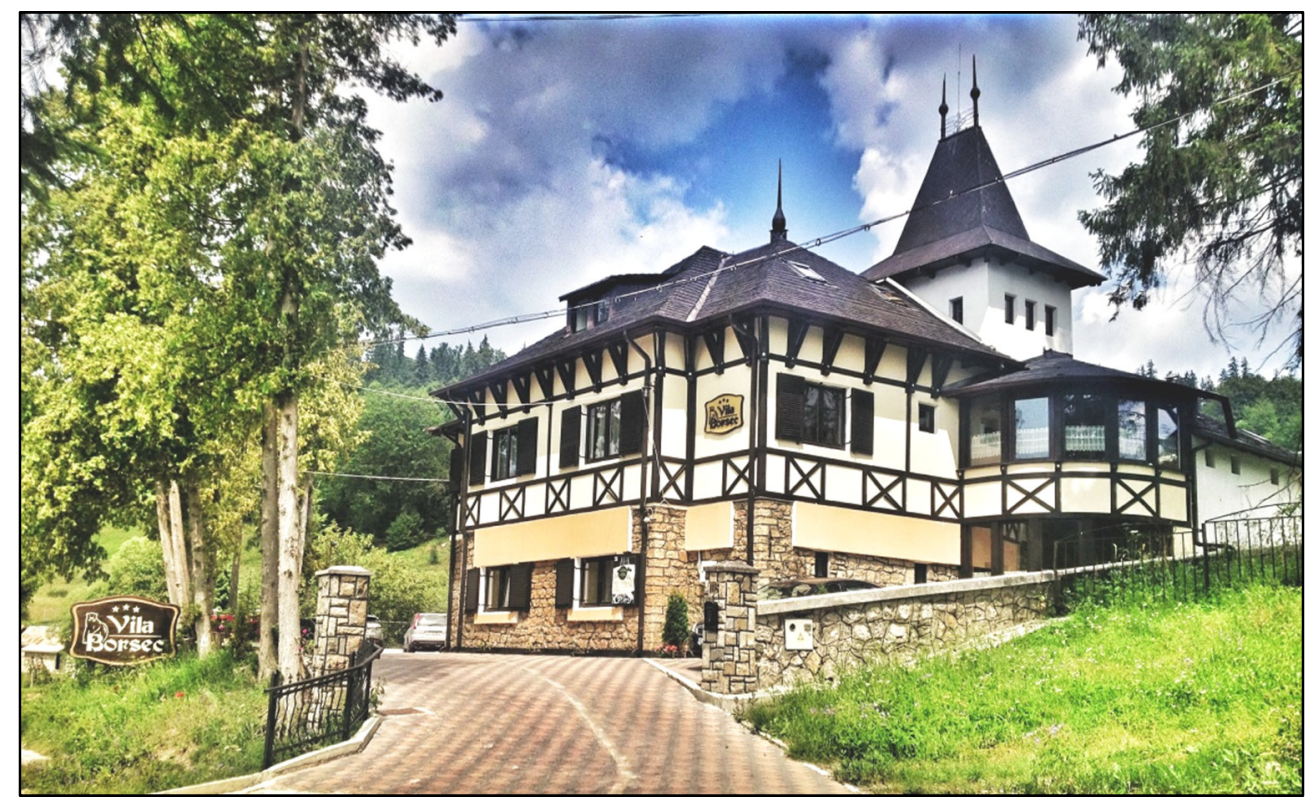

Fig. 2. Borsec Villa, recently rehabilitated.

(Source: J. Csatlós) 
The National Tourism Authority is the organisation which provides free information and data on the existing accommodation units in Romania, up until the previous year. In 2016, according to official data, there were 33 units $(759$ beds) in Borsec, villas representing $12.2 \%$ of the total number of units and $25.5 \%$ of the total number of beds. The five villas are: 7 Springs (7 rooms and 22 beds); Villa Bella ( 15 rooms and 30 beds), Villa Riki (23 rooms and 46 beds), Villa Sport with two buildings, comprising 42 rooms and 96 beds, all three star rated, with the exception of one (2 star rating) and Villa Anna, available only in summer ( 4 rooms and 16 beds). Another aspect worth mentioning is that some villas were renovated and converted into pensions or guesthouses - for example, the former Villa No. 17, Dalia, became Borostyanko Pension; Villa No. 41 - Iuliu's Pension; Villa No. 28 - Korona Pension; Villa No. 65 - Trandafirul Pension.

\section{CONCLUSIONS}

A positive fact is that on the $16^{\text {th }}$ February 2017, the town of Borsec was once again classified as a national resort. This is partly due the "Speranţa" Ski Complex, which attracts a large number of tourists, thus removing the seasonality disadvantage, and the future multifunctional spa, which will be opened soon. The latter will provide, besides different types of treatment, the possibility for R\&R all year long. Based on the two prior mentioned units, we consider the continuation of the rehabilitation and expansion of Borsec to be crucial. It is equally important to reconstruct the historical buildings on 7 Springs Alley and the villas, in a traditional style, and give them new functions.

Likewise, a part of remaining villas are included in the architectural heritage of Borsec: Villa No. 60 (Vasalopol) - 1880, Villa No. 56 (Barbu) - 1896, Villa No. 14 (Szentkovits) - 1933 - 1935, Villa Nr. 51 (Emil), built in 1936, Villa No. 53 (Doru) - 1936, the ruins of Babám Villa. Unfortunately, a series of buildings such as: Villa No. 17 (Bernstein), Villa No. 19 (Stoica), Villa No. 20 (Heiter), Villa No. 71 (Budapest), Villa No. 15 (Nefelejts), Villa No. 23 (Csilla), Făget Restaurant etc., erected in the $20^{\text {th }}$ century, included on the list of historical monuments, have been demolished.

The tourism rehabilitation and remodeling of Borsec involves tremendous financial and managerial efforts, the state playing a major role in providing a quality infrastructure, through investment and creating a stimulative legislative framework (Tofan, 2012a). All these actions aim at raising the spa product at European standards of quality, as the international demand for this type of tourism is increasing. This will allow for a proper capitalization of Borsec spa potential, for a large number of Romanian and foreign tourists. 


\section{R E F E R E N C E S}

1. Călimănescu, S., Zaharia, A. (1981), Borsec: Mic îndreptar turistic, Edit. SportTurism, Bucureşti.

2. Ciangă, N. (1997), Turismul din Carpaţii Orientali. Studiu de Geografie Umană, Edit. Presa Universitară Clujeană, Cluj-Napoca.

3. Ciangă, N., Dezsi, Șt. (2007), Amenajare turistică, Edit. Presa Universitară Clujeană, Cluj-Napoca.

4. Farkas, A. (2004), Istoria Borsecului în imagini, Edit. Demaco, Odorheiu Secuiesc.

5. Farkas, A. (2007), Borsec - Istoricul îmbutelierii apei minerale, Edit. Status, Miercurea-Ciuc.

6. Grama, N., Negru, R. (2012), Borsec, o amintire amară, Argument, nr. 4, Studii şi cercetări ştiinţifice de arhitectură şi urbanism, Bucureşti, 143-156.

7. Orban, B. (1868), A szekely föld leirasa (Descrierea secuimii), Vol. I, II, III, Budapesta.

8. Răucescu, Cozan, D. (1977), Depresiunea Borsec. Caracterizare geograficoeconomică cu priviri speciale asupra turismului, manuscris, Facultatea de Geografie şi Geologie, Iași.

9. Tofan, G. B. (2012a), Tourism Restoration and Remodelling of Borsec Resort, Romanian Review of Regional Studies, Cluj-Napoca, 8 (1): 87-92.

10. Tofan, G. B. (2012b), The Drăgoiasa-Tulgheș Depressionary Alignment. The Tourism Potential, Arrangement and Capitalization, Studia UBB, Geographia, Cluj-Napoca, 57 (2): 171-184.

11. Tofan, G. B. (2013a), Current Tendencies Regarding the Tourism Infrastructure of Drăgoiasa-Tulgheș Depression Alignment, Annals of the University of Oradea, Geography Series, 23 (1): 35-44.

12. Tofan, G. B. (2013b), Specific Features of the Tourist Flow in Borsec Resort, Annals of University of Bucharest, Geography Series, 52: 155-162.

13. Tofan, G. B. (2013c), Componenta nordică a ulucului depresionar din Grupa Centrală a Carpaților Orientali (Drăgoiasa-Glodu-Bilbor-Secu-Borsec-Corbu-Tulgheș), Edit. Presa Universitară Clujeană, Cluj-Napoca.

14. Tofan, G. B. (2014), The history of Borsec mineral water bottling, Studia UBB, Geographia, Cluj-Napoca, 59 (1): 165-176. 
15. Tofan, G. B., Niță, A. (2014), Some Actual Aspects about the Tourism Accomodation in Harghita County, GeoJournal of Tourism and Geosites, Oradea-Gdańsk, 7 (2): 158-167.

16. Tofan, G. B., Niță, A. (2015), Borsec. Harta geografico-turistică, scara 1: 30000 (cu text privind caracterizarea geografică şi obiectivele turistice, în limba română, maghiară şi engleză), tipărit la DHM, Bucureşti.

17. ${ }^{* * *}$ (2005), Planul Local de Dezvoltare Durabilă a orașului Borsec.

18. *** (2006), Strategia de Dezvoltare Locală și Turistică a orașului Borsec.

19. *** (2012), Planul urbanistic general al oraşului Borsec, volumul Memoriu General.

20. http://turism.gov.ro/web/autorizare-turism, consulted on 24 September, 2017.

21. http://www.harghita.insse.ro, consulted on 24 September, 2017. 